\title{
THE EFFECT OF INTELLECTUAL CAPITAL ON FINANCIAL PERFORMANCE IN THE ASEAN TELECOMMUNICATIONS SECTOR
}

\author{
Christandy Adriel \\ Universitas Ciputra Surabaya
}

\begin{abstract}
Telecommunication sector plays an important role in people's life, but its service in ASEAN nations are not as good as other nations. Currently, ASEANs telecommunication sector of financial performance (FP) is on a poor level and needs to be improved. Intellectual capital (IC) can increase FP. Every IC's component affects the FP, and this was tested on this research to see which component of IC is good to be invested to increase company's FP. Independent variables used on this research are human capital efficiency (HCE), structural capital efficiency (SCE), relational capital efficiency (RCE), and capital employed efficiency (CEE). The dependent variable is return on assets (ROA). This research used pooling data method from financial statements of ASEAN telecommunication company in the period of 2011 to 2018 . The number of samples which fulfils the criteria were 273 samples. SPSS 20 th version was used to analyses the data. The results indicate that FP is affected positively and significantly by HCE and CEE. However, SCE has a negative effect on FP significantly, while RCE does not affect FP.
\end{abstract}

Keywords: intellectual capital, financial performance, E-VAIC, ASEAN telecommunication

\section{INTRODUCTION}

In this modernization era, the development of technology is increasing rapidly. Technology is starting to become a necessity in various aspects of individual's life. Cascio \& Montealegre (2016) stated that currently, technology, especially information and communication technology, has change business attitudes in creating and capturing value, how and where business work, and how

\footnotetext{
*Corresponding Author.

e-mail: christandyadriel@gmail.com
} 
business communicate and interact. In terms of education, Bulman \& Fairlie (2016) stated that in most developed countries, the use of technology in the education system is quite common. Some researches show that technology has become a major tool for humans in carrying out activities.

A discussion by Cascio \& Montealegre (2016) shows that information and communication technology (ICT) has an important role in human life. ICTs cannot be used without the services of telecommunications sector companies. Therefore, the existence of telecommunications sector companies, especially those engaged in providing internet connection services and other companies that support the companies' technicality is important.

The importance of ICTs in life is inevitable, but ASEAN countries still cannot provide telecommunications services as well as other countries in the world. The State of Mobile Network Experience survey in 2019 by Open signal shows data on the quality of cellular connectivity services in 87 countries in the world (Boyland, 2019). According to this survey, the ASEAN was ranked as: Singapore ranked 5th, Myanmar ranked 40th, Vietnam ranked 43rd, Malaysia 55th, Philippines ranked 71st, Indonesia ranked 72nd, Thailand ranked 76th, Cambodia ranked 78th. Laos and Brunei Darussalam are not included in this survey. Singapore was the only ASEAN country that is listed on the top ten ranks. The other seven countries were still in low rank, which reflects the low quality of mobile internet in those nations. The low quality of telecommunications in those seven nations shows that they have lower competitiveness compared to other nations in the world.

Binder Dijker Otte's (BDO) Telecommunications Risk Factor Survey (2018) shows that there are 5 risks that arise in the telecommunications sector, including the exchange rate or changes in the value of foreign currencies, an increased competition, the rapidness of technological development that replaces previous technology, difficult access to receive funding, and interest rates. That survey shows that the credit ratings of telecommunications sector companies was not as good as before. In addition, it was also said that profit per customer in this sector has declined. BDO (2018) states that the telecommunications sector market is saturated. The telecommunications sector is experiencing problems where there is no new market that could be targeted, so companies in this sector compete for the same customers. The survey also shows that the emergence of new competi- 
tors was a problem because it increases the number of competitors. The decreasing amount of profit per customer and increasing competition could have a negative impact on corporate income in this sector. This decline in income will also affect the profitability of the company. Profitability is one of the benchmarks of FP (Donkor, 2018). So, the decline in profitability impacts on the decline in financial performance valuation as well. One example that illustrates the decline in FP in the telecommunications sector was in the Indonesian state. Deha (2019) stated that the FP of telecommunications sector companies in Indonesia are experiencing a decline due to an intense competition. For example, PT Telekomunikasi Indonesia (Persero) Tbk experienced a decrease in revenue from Rp 22.14 trillion in 2017 to $\mathrm{Rp} 18.03$ trillion in 2018 or equivalent to 18.57 percent decrease (Deha, 2019).

The increase of competition on this sector requires companies to increase their competitiveness. One component that can help companies improve their competitiveness is innovation in various aspects of the company. This is supported by a research of Belitz et al. (2018) which stated that the demands to be innovative and competitive greatly affect businesses in a developing economy. Belitz et al. (2018) also stated that these challenges can be faced by investing in modern machinery assets and knowledge-based capital. Corporate knowledge on the importance of knowledge-based capital makes many companies begin to realize that tangible assets are not enough for the company to compete against their competitor. Companies need knowledge assets that are measured by Intellectual Capital (IC) (Wijaya, 2012).

Stewart (1997) and Edvinsson \& Malone (1997) stated that IC consists of three components, which are human capital (HC), structural capital (SC), and relational capital (RC). HC refers to abilities possessed by employees which can be exemplified by knowledge and skills (Ozkan et al., 2016). SC is the infrastructure used by HC in creating value (Xu et al., 2019). RC is a good relationship that is maintained by the company towards external stakeholders (Sidharta \& Affandi, 2016). According to Pulic (1998) HC, SC, and RC cannot function if they are not supported with tangible assets. As an illustration, Bontis (1998) stated that one example of SC that can be owned by a company is the manufacturing process. The manufacturing process cannot be implemented without tangible assets in the form of machinery or other production of 
equipment; that is why tangible assets are also important to be examined in IC measurement. The efficiency of the tangible asset is also measured in IC measurement. Tangible assets are indicated by capital employed (CE) (Ahmad \& Ahmed, 2016); in other words, CE can also be classified as a component of IC. Therefore, the IC components that will be examined in this study are HC, SC, $\mathrm{RC}$, and CE.

There are previous studies that examines the relationship of IC to FP and the results of this studies indicate a significant positive relationship (Wijayani, 2017; Maharani \& Faisal, 2019). Previous researches also examine the relationship of each IC component to FP. The studies show inconsistent results, where there were studies that found that HC measured by Human Capital Efficiency (HCE) was an IC component that had the most significant influence (Ozkan et al., 2016). While there are other researches that show RC is the component with the most significant influence towards FP (Sardo et al., 2018). D•enopoljac et al. (2016) research shows that only Capital Employed Efficiency (CEE) has a significant positive effect on FP.

A research by Sardo et al. (2018) shows that SC measured by Structural Capital Efficiency (SCE) has a significant relationship to FP, but the result from Ozkan et al. (2016) study shows that the relationship of SCE to FP is insignificant. Some of these differences forms a gap that needs to be researched further. Some of this research was conducted in different sectors, such as banks (Ozkan et al., 2016), the ICT industry (D•enopoljac et al., 2016) and hospitality (Sardo et al., 2018). The researcher chooses the telecommunications sector as a research subject to see whether there are differences with researches that has been done on other sectors.

The sample used in this study is the annual report of telecommunications sector companies, especially companies that provide internet connection services and other company that supports them. The annual reports used are from the year of 2011 to 2018 . The samples are taken since 2011 because it is the initial year of industry 4.0 development (Bakkari \& Khatory, 2017; Vogel-Heuser \& Hess, 2016). Industry 4.0 is used as a basis for determining data collection because ICT has an important role in industry 4.0 (Roblek et al., 2016; Bakkari $\&$ Khatory, 2017). The use of knowledge-based capital or IC is also a supporting factor in industry 4.0 (Toro et al., 2015; Haddara \& Elragal, 2015). The results 
of this study were expected to contribute to the development of knowledge regarding the Intellectual Capital component and its effect on Financial Performance.

\section{METHOD}

\section{Population and Sample}

The population group of this study was companies in the telecommunications sector which are listed on the stock exchanges in 10 ASEAN countries. The sampling method in this study was purposive sampling that focus on internet connection services and other companies that supported the technical provision of these services companies. The companies must have published annual reports between 2011 and 2018. They used English and/or Indonesian language on their annual reports. After eliminating the data, the sample includes 273 annual reports. The data are collected from companies that are listed on the stock exchanges of Indonesia, Malaysia, Singapore, the Philippines, Thailand, and Myanmar. The annual reports were obtained from the respective stock exchange websites, the related company websites, or other websites that provide related annual reports.

\section{Operational Definition and Variable Measurement Intellectual Capital}

IC on this research was measured using E-VAIC Plus (E-VAIC+) by Ulum (2017). E-VAIC + corrects the weakness of previous measurements, such as Value Added Intellectual Coefficient by Pulic (1998), Modified Value-Added Intellectual Coefficient (MVAIC) by Ulum et al. (2014), and E-VAIC Model by Nazari \& Herremans (2007).

While E-VAIC Model by Nazari \& Herremans (2007) have added Customer Capital Efficiency (CCE) which corrects previous measurements weakness. CCE in this measurement is still used to calculate structural capital efficiency (SCE). Stewart (1997), Edvinsson \& Malone (1997), and several other researchers stated that customer capital (CC) or relational capital (RC) must stand independently, and not incorporated into structural capital (SC). E-VAIC+ by Ulum (2017) corrects this weakness, so this measurement was used on this research. 
1. Value Added (VA)

VA describes a company's ability to create value (Rochmadhona et al., 2018). The formula for calculating VA is as follows:

$$
V A=O P+E C+D+A
$$

where OP is Operating Profit, EC is Employee Cost, D is Depreciation, and $\mathrm{A}$ is Amortization.

2. Human Capital Efficiency (HCE)

The HCE represents the value added of the company for each rupiah invested in HC (Rochmadhona et al., 2018). HCE is used to measure HC (Nazari \& Herremans, 2007). The HCE formula is as follows:

$$
H C E=\frac{V A}{H C}
$$

where VA is value added and Human Capital (HC) is the total of employee expenses.

3. Innovation Capital Efficiency (InCE)

InCE describes VA obtained from innovation and development that is invested in $\mathrm{R} \& \mathrm{D}$ costs (Rochmadhona et al., 2018). InCE calculation is as follows:

$$
\operatorname{InCE}=\frac{\operatorname{InC}}{V A}
$$

where Innovation Capital ( $\mathrm{InC}$ ) is R\&D expenses and VA is value added.

4. Process Capital Efficiency (PCE)

PCE shows the combined value of a company's value creation process (Rochmadhona et al., 2018). The PCE calculation is as follows:

$$
P C E=\frac{P C}{V A}
$$

where process capital (PC) is the total of amortization and depreciation expenses. VA is value added.

5. Relational Capital Efficiency (RCE)

RCE used to measure RC (Ulum, 2017). RCE calculation is as follows:

$$
R C E=\frac{R C}{V A}
$$


where RC is relational capital that can be measured by marketing expenses (Ulum, 2017) and VA is value added.

6. Structural Capital Efficiency (SCE)

SCE shows the level of contribution of company resources and infrastructure in increasing employee productivity (Rochmadhona et al., 2018). SCE is used to measure SC (Nazari \& Herremans, 2007). The SCE formula is as follows:

$$
S C E=\operatorname{InCE}+P C E
$$

where InCE is Innovation Capital Efficiency dan PCE is Process Capital Efficiency.

7. Intellectual Capital Efficiency (ICE)

ICE shows the efficiency of using information, abilities, knowledge, relationships, and experience as intellectual property (Rochmadhona et al., 2018). ICE formula is as follows:

$$
I C E=H C E+S C E+R C E
$$

where HCE is human capital efficiency, SCE is structural capital efficiency, and RCE is relational capital efficiency.

8. Capital Employed Efficiency (CEE)

CEE shows the level of VA in assets owned by the company (Rochmadhona et al., 2018). The CEE formula is as follows:

$$
C E E=\frac{V A}{C E}
$$

where VA is value added and Capital Employed (CE) is the total assets book value.

9. Extended VAIC Plus (E-VAIC +)

The final step is E-VAIC +. E-VAIC + describes the intellectual abilities of a company (Nazari \& Herremans, 2007). E-VAIC + can be calculated with the following formula:

$$
E-V A I C+=I C E+C E E
$$

where ICE is intellectual capital efficiency and CEE is capital employed efficiency. 


\section{Financial Performance}

Financial performance (FP) can be measured using many proxies. FP measurements in several studies used similar proxy but with various combinations (Rochmadhona et al., 2018; Maharani \& Faisal, 2019; D•enopoljac et al., 2016; Sidharta \& Affandi, 2016; Bayraktaroglu et al., 2019). Based on that research results, this research uses Return on Assets (ROA) as a FP proxy. ROA is used as a proxy because this study wants to see the level of corporate returns, especially from the perspective of assets owned by the company, so that this proxy was suitable (Subramanyam, 2014; Bringham \& Houston, 2019).

\section{Return on Assets (ROA)}

According to Rochmadhona et al. (2018), ROA is a ratio that can show how effective a company is in using its assets for profit. ROA can be measured by the following formula:

$$
R O A=\frac{\text { Net Income }}{\text { Total Assets }}
$$

\section{Data Analysis Method}

The independent variable on this research is IC, while the dependent variable is FP. This research wanted to test the effect of each component of IC on FP which is measured with ROA where the data was obtained from the company's annual reports. Therefore, this research is classified as a quantitative study with a correlational method.

\section{RESULTS}

\section{Descriptive Analysis}

Table 1 illustrates the sample data of the annual reports that were processed in this study. The minimum value of each proxy was negative. The negative value of each proxy was due to the losses that telecommunications sector companies in ASEAN countries sampled has suffered. There are 70 samples of annual report data from a total of 273 annual reports that reported losses. The loss value 
causes the proxy calculation to be negative. The negative ROA value shows that with the total amount of the company's existing assets, the company failed to gain profit, and instead the company suffered losses (Wild et al., 2003).

Table 1 Descriptive Statistic Analysis

\begin{tabular}{lccccc}
\hline & N & Minimum & Maximum & Mean & $\begin{array}{c}\text { Std. } \\
\text { Deviation }\end{array}$ \\
\hline ROA & 273 & $-0,35$ & 0,38 & 0,487 & 0,10827 \\
HCE & 273 & $-17,11$ & 35,07 & 4,4492 & 4,78220 \\
RCE & 273 & $-3,61$ & 3,65 & 0,0853 & 0,44879 \\
SCE & 273 & $-27,27$ & 10,38 & 0,3975 & 2,06265 \\
CEE & 273 & $-0,19$ & 0,69 & 0,1860 & 0,13487 \\
\hline
\end{tabular}

The mean value is the average value of the entire sample analyzed in this study. The mean value of ROA in this study was 0.0487 . ROA mean value tends to lean towards the minimum value of sample. This shows that the average telecommunications sector company tends to have a low ROA level. It illustrates the company's performance, in terms of total asset value, which tends to be bad. The mean value for the IC component variable in this study also shows a tendency that is close to the minimum value. This is in line with the value of ROA. The mean value that tends to be close to the minimum value indicates the efficiency of human capital, structural capital, relational capital, and employed capital which tends to be bad.

The standard deviations of the ROA, RCE, and CEE variables are below one, which is lower than the standard deviation values for the HCE and SCE variables. This shows that the value of ROA, RCE, and CEE variables from each observed annual report data is closer to the average than the sample value of the HCE and SCE variable on the annual report data.

\section{Classic Assumption Test}

\section{Normality, Autocorrelation, Multicollinearity, and Heteroscedasticity Test}

Based on the results of the normality test in Table 2, the sample data of annual reports in this study are normally distributed because the significance value is above 0.05 . The sample data of financial statements that are normally 
distributed shows that the sample data of financial statements has a value that lean towards the average. Table 3 illustrates that the Durbin-Watson value is 0.829 . The Durbin-Watson value is between -2 to 2 , so it can be concluded that there is no autocorrelation found in the data. The absence of autocorrelation shows that there is no correlation between the current observation period and the previous period. Next, the tests results on Table 4 indicate that there are no variables that have a VIF value above 10 . Thus, it can be concluded that there are no symptoms of multicollinearity. The absence of multicollinearity symptoms indicates that the independent variables HCE, SCE, RCE, and CEE do not have a high correlation. Based on the results on table 5 calculation, heteroscedasticity on each IC variable towards FP does not occur because the significance value is above 0.5 . From the analysis, it can be said that there was homoscedasticity for the sample data used.

Table 2 Normality Test

\begin{tabular}{cc}
\hline $\mathbf{N}$ & $\mathbf{2 7 3}$ \\
\hline Asymp. Sig. (2-tailed) & 0,057 \\
\hline
\end{tabular}

Table 3 Autocorrelation Test

\begin{tabular}{cc}
\hline Model & Durbin-Watson \\
\hline 1 & 0,829 \\
\hline
\end{tabular}

Table 4 Multicollinearity Test

\begin{tabular}{lc}
\hline & $\begin{array}{c}\text { Collinearity Statistics } \\
\text { VIF }\end{array}$ \\
\hline HC & 1,266 \\
E & 1,103 \\
SCE & 1,099 \\
RC & \\
E & \\
\hline
\end{tabular}


Table 5 Heteroscedasticity Test

\begin{tabular}{ll}
\hline & Sig. \\
\hline HCE & 1,000 \\
RCE & 1,000 \\
SCE & 1,000 \\
CEE & 1,000 \\
\hline
\end{tabular}

\section{F-test (Goodness of Fit)}

The results of the analysis of the sample data on the annual reports show a calculated $\mathrm{F}$ value of 233.121 which is greater than the $\mathrm{F}$ table of 3.84 . Moreover, it is stated with a positive sign, which shows the direction of a positive relationship. The significance value of the IC component on FP is 0,000 , which is less than 0.05 , indicating that the independent variable can affect FP simultaneously.

Table 6 F-test

\begin{tabular}{lll}
\hline & F & Sig \\
\hline FP & 233,121 & $0,000^{\mathrm{b}}$ \\
\hline
\end{tabular}

\section{Multiple Linear Regression Test}

Based on the results of the regression test analysis, the equation can be formulated as follows:

$\mathrm{FP}=-0,84+0,005 \mathrm{HCE}-0,004 \mathrm{SCE}-0,008 \mathrm{RCE}+0,600 \mathrm{CEE}$

The HCE shows a coefficient of 0.005 , indicating a direction of a positive relationship. In other words, if the value of HCE increases, then the company's FP as measured by ROA will also increase in the direction of HCE. The SCE coefficient of -0.004 indicates a direction of a negative relationship. In other words, if the HCE value increases, then the company's FP as measured by ROA will decrease inversely with SCE. The RCE coefficient of -0.008 indicates a 
direction of a negative relationship. In other word, if the value of RCE increases, the company's FP as measured by ROA will decrease inversely with SCE. The CEE coefficient of 0.600 indicates a direction of a positive relationship. In other words, if the CEE value increases, then the company's FP as measured by ROA will increase in the direction of CEE.

Table 7 shows the significance value of HCE against FP, which is smaller than 0.05 . According at the regression results, the direction of the relationship is positive so it can be concluded that there is a significant positive effect between HCE on FP. In result, the first hypothesis is accepted. Table 7 shows the SCE significance value for FP is smaller than 0.05. According at the regression results, the direction of the relationship is negative so it can be concluded that there is a significant negative effect between SCE on FP. Due to this reason, the second hypothesis is rejected. Table 7 shows the significance value of RCE against FP that is greater than 0.05 so it can be concluded that RCE does not affect FP. In result, the third hypothesis is rejected. Lastly, Table 7 shows the CEE significance value for FP is smaller than 0.05. According at the regression results, the direction of the relationship is positive so it can be concluded that there is a significant positive effect between CEE on FP. Hence, the fourth hypothesis is accepted.

Table 7 t-test

\begin{tabular}{cccl}
\hline & B & Sig. & \multicolumn{1}{c}{ Explanation } \\
\hline HCE & 0,005 & 0,000 & Significant \\
SCE & $-0,004$ & 0,014 & Significant \\
RCE & $-0,008$ & 0,248 & Insignificant \\
CEE & 0,600 & 0,000 & Significant \\
\hline
\end{tabular}

\section{Adjusted $\mathbf{R}^{2}$ Test}

The results of the analysis of the sample data from the annual reports show the adjusted R2 value of each IC component to ROA is 0.773 . It shows that each IC component can explain the FP variable by $77.3 \%$ while the remaining $22.7 \%$ is explained by other variables not examined in this study. 
Table 8 Adjusted $\mathrm{R}^{2}$ Test

\begin{tabular}{cc}
\hline & $\begin{array}{c}\text { Adjusted } \\
\mathbf{R}^{2}\end{array}$ \\
\hline FP & 0,773 \\
\hline
\end{tabular}

\section{DISCUSSION}

\section{Effect of HCE on FP}

The results of the data analysis indicated that HCE had a significant positive effect on FP. These results illustrate that investments made by companies on their workforce, in terms of developing the skills, abilities, expertise, and experience of employees can improve the company performance as measured by ROA. The result was also in line with several previous studies which show that HCE affects FP significantly and positively (Rahim et al., 2017; Danjuma \& Ajike, 2016; Ozkan et al., 2016; Xu et al., 2019).

\section{Effect of SCE on FP}

The results of the analysis of the annual report data samples indicate that SCE has a negative influence on FP as measured by ROA. These results illustrated that the financial performance of telecommunications sector companies in ASEAN, especially for the period of 2011 to 2018, will increase if the value of SCE decreases. In other words, the relationship was inverse. Based on the definition of SCE according to Sidharta \& Affandi (2016), increasing SCE will also increase HCE, which means that when HCE positively affects FP, SCE will also affect FP positively.

One of the research obstacles is finding financial reports that do not report the costs of research $\&$ development $(\mathrm{R} \& \mathrm{D})$. R\&D costs are used to measure InCE. InCE is one of the components needed to calculate the value of SCE. This causes the SCE value to be lower than it should be, which then shows that the effect of SCE on FP in this study is negative.

\section{Effect of RCE on FP}

The results indicate that RCE has no influence on ROA. The investment made by ASEAN telecommunications companies in building relationships with 
the external stakeholders does not show a contribution in improving the company's performance. The lack of influence between RCE on FP might not indicate the absence of marketing cost contributions used to build relationships with corporate partners to increase FP as measured by ROA. Companies that do marketing might not receive the impact in the same period. Costs incurred by the company for product marketing may attract customer interest on buying the product, but purchases are not made in the same period as the product marketing period. Therefore, the relationship of marketing costs with an increase in FP is not apparent.

This research stumble upon obstacle where the information of marketing costs used to measure RCE was not available on some of the annual reports. The limitations of information regarding marketing costs affect the results of research, which resulted in no influence found between the two variables. The results of this study were confirmed by the results of previous study by Andreeva \& Garanina (2017) which shows that RCE does not affect FP.

\section{Effect of CEE on FP}

CEE in this research shows the same effect as HCE. CEE shows a significant positive effect on FP measured using ROA. This shows that the use of tangible assets in generating value added in telecommunications companies in ASEAN in the period 2011 to 2018 had an impact on the increase of FP. This is in line with a research conducted by Onumah \& Duho (2019) which shows that CEE significantly affected FP.

\section{Conclusion and Implication}

Based on the research result, it could be concluded that only HCE and CEE have positive significant effect on company's FP. SCE have a negative significant effect towards company's FP while RCE does not have influence on company's FP. These results shows that companies on telecommunication sector in ASEAN nations rely most on their human capital and physical capital to make a better financial performance. The results of this research illustrate which IC components that affect company's FP in the telecommunications sector in ASEAN countries for 2011 to 2018 which are proxied by the value of ROA. During that 
year span, ASEAN telecommunications companies were experiencing losses. Companies need to make efficiency to reduce expenses and suppress losses.

Seeing the results of this research, telecommunications sector companies in ASEAN would be better off in investing their funds to develop human resources. Investment in human resources can be done by increasing the number of employees or dismiss employees with bad performance evaluation and company can replace them with new employees with competencies. Another way is to improve the quality of employees that the company already has by conducting employee trainings. The increase in HC will simultaneously increase the company's ROA, which will make the valuation of the company's financial performance better. Improving the financial performance will bring a variety of good impacts for the company, where increased interest of investors in investing funds into the company being one of them. These increase on investments earned by the company can increase the amount of funds owned by the company so that the company can further develop its operations to improve the condition of the company.

Another way to increase ROA that companies can invest is in tangible assets. CEE illustrates the ability of tangible assets to produce VA (Rochmadhona et al., 2018). For example, investment in tangible assets that can increase the company productivity is adding signal towers. Increased productivity will have an impact on the company's ability to provide more services to its customers and will generate more income. The increase of income itself is a form of VA increment, where increase of VA value will also increase CEE value of the company. The impact of CEE value increment also affects ROA value increment. Therefore, increasing the efficiency of tangible assets to increase production capacity can also be used to increase company profitability.

Measurement of SCE and RCE in this study encountered problems where the data needed for the calculation of these variables was not available in the company's annual reports. This unavailability of information makes it difficult to measure the actual results. To get closer to the actual condition of the company, companies need to provide all information needed in calculating each measurement. So, the results can describe the actual condition of the company. By reflecting the actual condition of the company, managers can make the right decisions for the survival of the company. 


\section{REFERENCES}

Ahmad, M. \& Ahmed, N. (2016). Testing the relationship between intellectual capital and a firm's performance: an empirical investigation regarding financial industries of Pakistan. International Journal of Learning and Intellectual Capital, 13(2-3), 250-272.

Andreeva, T. \& Garanina, T. (2017). Intellectual Capital and Its Impact on the Financial Performance of Russian Manufacturing Companies, 11(1).

Bakkari, M. \& Khatory, A. (2017). Industry 4.0: strategy for more sustainable industrial development in SMEs. Proceedings of the IEOM 7 th International Conference on Industrial Engineering and Operations Management, Rabat, Morocco, 11-13.

Bayraktaroglu, A. E., Calisir, F., \& Baskak, M. (2019). Intellectual capital and firm performance: an extended VAIC model. Journal of Intellectual Capital, 20(3), 406-425.

BDO (2018). BDO's 2018 Telecommunications Risk Factor Survey: Is Telecom Companies' Proactive Approach Paying Off? Diakses pada 2019, Oktober 1 dari https://global- www.bdo.global/en-gb/microsites/2018-telecommunications-risk-factor-survey/2018- telecommunications-risk-factor-survey.

Belitz, H., Le Mouel, M., \& Schiersch, A. (2018). Company productivity increases with more knowledge-based capital. DIW Weekly Report, 8(4), 49-55.

Bontis, N. (1998). Intellectual capital: an exploratory study that develops measures and models. Management Decision, 36(2), 63-76.

Boyland., P. (2019). The State of Mobile Network Experience: Benchmarking Mobile on The Eve of The $5 G$ Revolution. Opensignal.

Bringham, E. F. \& Houston, J. F. (2019). Fundamentals of Financial Management. Boston: Cengage.

Bulman, G. \& Fairlie, R. W. (2016). Technology and education: computers, software, and the internet. Handbook of the Economics of Education, Elsevier, 5, 239-280.

Cascio, W. F. \& Montealegre, R. (2016). How technology is changing work and organizations. Annual Review of Organizational Psychology and Organizational Behavior, 3, 349-375. 
Danjuma, K. J. \& Ajike, A. M. (2016). Human capital efficiency and corporate performance: the Nigerian perspective. The International Journal of Business \& Management, 4(3), 1.

Deha, D. (2019). Insight: Indonesia's Telco Industry Needs Consolidation. Diakses pada 2019, Oktober 24 dari https://theinsiderstories.com/a-number-ofoperators-hits-the- financial-performance-of-the-indonesian-telco-industry/

Donkor, J., Donkor, G. N. A., Kankam-Kwarteng, C., \& Aidoo, E. (2018). Innovative capability, strategic goals and financial performance of SMEs in Ghana. Asia Pacific Journal of Innovation and Entrepreneurship, 12(2), 238-254.

D•enopoljac, V., Janoševic, S., \& Bontis, N. (2016). Intellectual capital and financial performance in the Serbian ICT industry. Journal of Intellectual Capital, 17(2), 373-396.

Edvinsson, L. \& Malone, M. (1997). Intellectual Capital: Realizing Your Company's True Value by Finding Its Hidden Brainpower. New York: Harper Business.

Haddara, M. \& Elragal, A. (2015). The readiness of ERP systems for the factory of the future. Procedia Computer Science, 64, 721-728.

Maharani, N. B. \& Faisal, F. (2019). Modal intelektual dan kinerja keuangan perusahaan. Jurnal Reviu Akuntansi dan Keuangan, 9(1), 12-21.

Nazari, J.A. \& Herremans, I.M. (2007). Extended VAIC model measuring intellectual capital components. Journal of Intellectual Capital, 8(4), 595609.

Onumah, J. M. \& Duho, K. C. T. (2019). Intellectual capital: its impact on financial performance and financial stability of Ghanaian Banks. Athens Journal of Business and Economics.

Ozkan, N., Cakan, S., \& Kayacan, M. (2016). Intellectual capital and financial performance: A study of the Turkish Banking Sector. Borsa Istanbul Review, 17(3), 190-198.

Pulic, A. (1998). Measuring the performance of intellectual potential in knowledge economy. 2nd McMaster Word Congress on Measuring and Managing Intellectual Capital by the Austrian Team for Intellectual Potential, 1-20.

Rahim, A., Atan, R., \& Kamaluddin, A. (2017). Human capital efficiency and firm performance: An empirical study on Malaysian technology industry. SHS Web of Conferences, 36(26). 
Roblek, V., Meško, M., \& Krape •, A. (2016). A complex view of industry 4.0. Sage Open, 6(2).

Rochmadhona, B. N., Suganda, T. R., \& Cahyadi, S. (2018). The competitive advantage between intellectual capital and financial performance of banking sector in ASEAN. Jurnal Kenangan dan Perbankan, 22(2).

Sardo, F., Serrasqueiro, Z., \& Alves, H. (2018). On the relationship between intellectual capital and financial performance: A panel data analysis on SME hotels. International Journal of Hospitality Management, 75, 67-74. Sidharta, I. \& Affandi, A. (2016). The empirical study on intellectual capital approach toward financial performance on rural banking sectors in Indonesia. International Journal of Economics and Financial Issues, 6(3), 1247-1253.

Stewart, T.A. (1997). Intellectual Capital: The New Wealth of Organizations. New York: Doubleday.

Subramanyam, K. R. (2014). Financial Statement Analysis. New York: McGrawHill Education.

Toro, C., Barandiaran, I., \& Posada, J. (2015). A perspective on knowledge based and intelligent systems implementation in industrie 4.0. Procedia Computer Science, 60, 362-370.

Ulum, I. (2017). Intellectual Capital: Model Pengukuran, Framework Pengungkapan, dan Kinerja Organisasi. Malang: Penerbit Universitas Muhammadiyah Malang.

Ulum, I., Ghozali, I., \& Purwanto, A. (2014). Intellectual capital performance of Indonesian banking sector: a modified VAIC (M-VAIC) perspective. International Journal of Finance \& Accounting, 6(2), 103-123.

Wijaya, S. P. (2012). Pengaruh intellectual capital terhadap profitabilitas pada perusahaan farmasi di BEI. Jurnal Ilmiah Mahasiswa Akuntansi, 1(3), 18-23.

Wijayani, D. R. (2017). Pengaruh intellectual capital terhadap kinerja keuangan perusahaan publik di Indonesia (studi empiris pada perusahaan manufaktur di BEI 2012-2014). Jurnal Riset Akuntansi dan Bisnis Airlangga, 2(1).

Wild, J. J., Subramanyam, K. R., \& Halsey, R. F. (2003). Financial Statement Analysis, (8 ${ }^{\text {th }}$ ed.). New York: McGraw-Hill Education.

Xu, J., Shang, Y., Yu, W., \& Liu, F. (2019). Intellectual capital, technological innovation and firm performance: evidence from China's manufacturing sector. Sustainability, 11(19), 5328. 